\title{
The Application of Molecular Biology
}

\author{
Robert C. Tait \\ Biotechnology Consultant, 2318 Cezanne Court, Davis CA 95616, USA
}

\begin{abstract}
Molecular biology methods have tremendous value not only in the investigation of basic scientific questions, but also in application to a wide variety of problems affecting the overall human condition. Disease prevention and treatment, generation of new protein products, and manipulation of plants and animals for desired phenotypic traits are all applications that are routinely addressed by the application of molecular biology methods. Because of the wide applicability of these methods, they are rapidly becoming a pervasive - some would argue invasive - aspect of our technologically based society. The public concerns that address the application of these methods should be addressed by informed public discussion and debate. While scientists can be extremely critical of the quality, interpretation, and significance of experimental results, they have a rather remarkable tendency to be non-judgmental of the relative social merits of many applications of scientific research. It remains a public responsibility to be sufficiently well-informed to critically assess the merits of applied science research and participate in a communal decision-making process regarding the extent to which a new technology will be allowed to affect society.
\end{abstract}

\section{Introduction}

The methods called recombinant DNA developed out of the scientific desire to address the fundamental hypothesis that the physical traits of a cell are encoded by the nucleic acids present in the chromosomes of the cell and changes in the structure and function of nucleic acid result in changes in cellular characteristics.

How has this new methodology succeeded in application to testing of fundamental scientific theories? Application of these methods to the study of developmental biology has provided significant support for the cell theory, which suggests that all organisms are composed of many individual cells, by allowing the investigation of the changes in gene expression that accompany the development of a mature organism. The ability to isolate, modify, and re-introduce specific genes has been instrumental in providing overwhelming evidence in support of the chromosomal theory of heredity, which suggests that the chromosomes within the individual cells control the physical traits of the cells. The isolation and sequence analysis of related genes from several different species and the study of the occurrence of alleles in wild populations have provided information that supports elements of the theory of evolution by natural selection, which suggests that complex organisms are derived from more primitive organisms by a process of accumulation of changes in physical traits of cells.

Development and continued refinement of the methods of molecular biology have been critical in the explosion of information regarding the role of nucleic acids in the control of the physical traits of cells. The increased understanding of the structure and function of the genome has also resulted in the appearance of molecular biology in everyday life. 
It is important to understand that scientific research can be divided into two general categories: basic and applied research. Basic research might be described as the search for a basic understanding of a problem area, while applied research can be thought of as applying the results of basic research to generate a useful product.

The scientific methods and the research topics that make up the field of molecular biology are obviously of interest to the scientific community involved in basic research, but why should these topics generate widespread interest and controversy among people who are not members of the scientific community? The increasing use of molecular biology methodology in applied research has been accompanied by the appearance of biomedical and production innovations that are of increasing public notice.

Understanding of scientific theory is rarely necessary for everyday application of a scientific principle. After all, a person need not understand either electricity or the internal combustion engine to be fairly confident that an automobile with a full tank of gas and a good battery will start when the key is turned in the ignition. It is not really necessary to understand the mechanics of technology to be able to use the products of technology. Consider that the vast majority of people in the United States understand how to use fire to cook and heat, yet very few of these people can start a fire in the absence of technological devices (matches or lighters, for example).

Recombinant DNA technology developed out of the desire to obtain large amounts of a purified gene to address various important hypotheses regarding gene structure and function. The concepts that allow recombinant DNA technology are fairly simple. Restriction endonucleases are proteins that cleave DNA in a sitespecific manner to generate specific, reproducible fragments of the DNA present in a chromosome. DNA fragments can be separated according to size by gel electrophoresis and stained with dyes that allow the detection of as little as $5 \times 10^{-9}$ gram of DNA. Digestion of a DNA fragment with several different enzymes can be used to establish a physical map of the positions of cleavage sites relative to one another - a restriction map of the DNA fragment. Restriction maps can provide direct correlation between the physical structure of a chromosome and the order of the genes present on the chromosomal DNA molecule.

DNA fragments can be inserted into cloning vectors designed to propagate in a suitable host. The vector serves two functions: a fragment inserted into the vector has been molecularly cloned away from other DNA fragments and once cloned, can be amplified by purification of the recombinant molecule. Large amounts of a very pure DNA fragment can be obtained by cloning the fragment in a vector. Molecular cloning of DNA fragments overcomes many of the problems associated with the isolation of rare DNA molecules and the preparation of sufficient amounts of DNA for many experiments.

These methods are of tremendous value in the analysis of the biological mechanisms that are involved in regulating gene expression and have contributed to a virtual revolution in molecular biology. The new information accumulates at a rate that causes a continuing re-evaluation of scientific theories regarding gene structure and function. The scientific debate that arises is part of the normal process of scientific evaluation. Experiments are designed to test theories, results are interpreted, and the results are compared with existing theories to determine whether the theories are consistent with the experimental results. Controversy is accepted among scientists as a normal part of the investigation process.

Recombinant DNA methods and their application to molecular biology problems have generated not only scientific debate, controversy, and re-evaluation of theories regarding gene structure and function, but have also generated significant public debate regarding safety, ethics, and economic potential of this type of research. These methods have been perceived as having tremendously powerful positive and negative social impacts, with both benefactors and detractors making misleading statements. Understanding how these methods can be applied to various specific problems can help illustrate why recombinant DNA methodology is no longer merely 
an investigative tool for molecular biologists, but is experiencing increasing application to common problems.

\section{Contributions to Genetic Screening and Analysis}

Molecular biology has provided several new tools, including restriction fragment length polymorphism (RFLP) analysis, the polymerase chain reaction (PCR), and DNA fingerprinting, that are becoming increasingly common in the determination of genetic traits of individuals. These methods of analysis are all based on the principles that since the DNA of an organism contains the genes that code for all of the physical characteristics of a specific individual and since each individual (with the exception of identical twins) has a unique combination of genes, a DNA sample isolated from an individual can be used to predict physical traits or to actually identify the individual out of a group.

\section{Restriction Fragment Length Polymorphism and RFLP Analysis}

RFLP analysis is based on the observation that there are slight differences in the nucleotide sequences of the same gene isolated from two different individuals. These nucleotide sequence differences can be used to distinguish the gene isolated from one individual from the same gene isolated from a different individual. Isolation and determination of the nucleotide sequences of the genes from both individuals would be a slow and expensive method of identification. Fortunately, the variation in nucleotide sequence will occassionally either inactivate or create the cleavage site for a restriction enzyme (Figure 1). When the DNA from two individuals is digested with the same restriction enzyme, the same gene can be present on DNA fragments of different sizes. The lengths of the restriction fragments carrying a specific gene are polymorphic, or of variable sizes, when an entire population of individuals is examined.

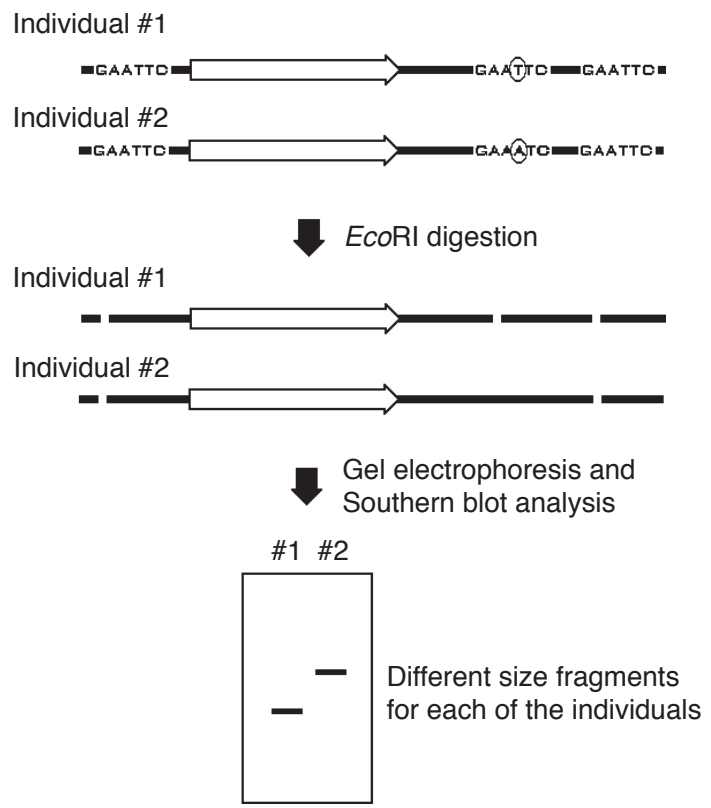

Figure 1. Minor variations in nucleotide sequence can lead to differences in the presence of restriction enzyme cleavage sites in different chromosomes. The same gene may be present on differen size DNA fragments in different individuals. In the example illustrated, the nucleotide sequences of two DNA fragments containing the same gene differ at only a single nucleotide residue, where a $\mathrm{T}$ in individual \#1 is replaced with an A in individual \#2 (residues are circled). This single base change inactivates an EcoRI cleavage site in individual \#2 (GAATTC changed to GAAATC). The same gene will be present on a different size EcoRI fragment in these two individuals. 
Figure 2. A family tree that traces the transmission of a genetic disorder from parents to children can sometimes be matched with a restriction fragment length polymorphism. In the example tree shown, normal individuals are indicated by open symbols and affected individuals by filled symbols. This pedigree traces transmission of a genetic disorder from an affected mother and unaffected father through their five children and seven grandchildren. When DNA from each individual is isolated and subjected to Southern blot analysis with a DNA probe for the affected gene, all samples should contain two copies of the gene examined (one on each of the pair of chromosomes that carry the gene). All samples examined contained a common band (A), which evidently corresponds to a normal copy of the gene. The unaffected male spouse of one child also contained a different band (B), which was transmitted to an unaffected grandchild. Band B corresponds to a normal copy of the gene with a polymorphism that changes the size of the DNA fragment without affecting gene function. In addition to the presence of band A, indicating a normal copy of the gene, all of the affected individuals contained a smaller band $(\mathrm{C})$. Band $\mathrm{C}$ serves as a physical marker that indicates the presence

of the defective gene. Since the affected individuals contained a normal copy of the gene in addition to the defective copy of the gene, the defective gene must be dominant, controlling phenotype in the presence of the normal gene.

Restriction fragment length variability can be examined by Southern blot analysis using a labeled probe for a specific gene to identify different fragments that carry slightly different copies of the same gene. Eukaryotes are generally diploid, or contain pairs of chromosomes, and a given gene will be located at the same position of a specific chromosome. Each eukaryotic cell will therefore contain two alleles or copies of the same gene (one on each of two copies of each chromosome). Since the sperm and egg are haploid and contain one rather than two copies of each chromosome, one chromosome in the fertilized diploid zygote comes from each of the two parents. One copy of each gene is maternal, or derived from the mother, and the other copy is paternal, or derived from the father. If the maternal and paternal genes were slightly different, an individual will carry two slightly different copies of the same gene. When these different alleles are associated with different restriction fragment sizes, the restriction fragments can be used as markers to track the alleles as they are passed from parents to progeny (Figure 2).

Medical research is identifying an increasing number of polymorphisms that are associated with specific genetic disorders. These polymorphisms may affect the gene involved in the disorder or may be simply associated with DNA that is very close to the defective gene. When association of a specific restriction fragment size with a particular genetic disorder is very high, that fragment can serve as a genetic marker for the disorder and can be used to screen for individuals who are carriers or victims of the disorder (Figure 3 ). With a recessive trait, heterozygous individuals with one copy of the defective gene will be carriers with a $50 \%$ probability of transmitting the defective gene to progeny and homozygous individuals with two defective alleles will have a $100 \%$ probability of transmitting the defective gene. RFLP analysis allows genetic counselors to examine the DNA of individuals who have a family history of a genetic disorder and determine the probability of 
Normal phenotype Affected phenotype

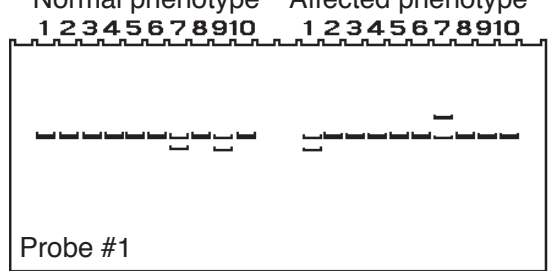

Normal phenotype Affected phenotype $12345678910 \quad 12345678910$

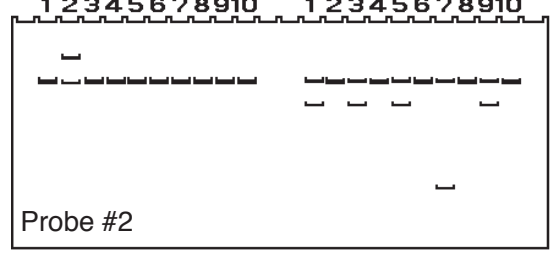

Normal phenotype Affected phenotype $12345678910 \quad 12345678910$

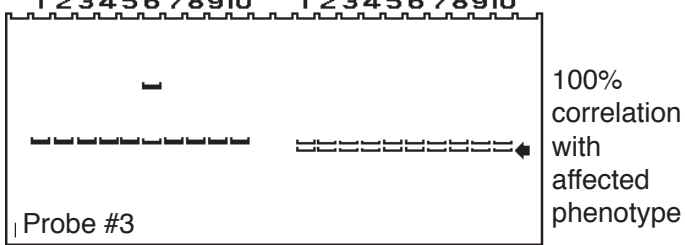

Figure 3. Choosing a restriction fragment length polymorphism as a marker for a genetic disorder involves finding a DNA probe that exhibits $100 \%$ correlation with the affected phenotype. In the illustration, the DNA of ten normal and ten affected individuals has been cleaved with a restriction enzyme and examined by Southern blot analysis with three different DNA probes. The fragments revealed with probe \#1 show only normal polymorphism - two normal and two affected individuals have different fragments. Results obtained with probe \#2 reveal that a fragment present in four affected individuals does not occur in any normal individuals, but six of the affected individuals examined do not contain this fragment. While probe \#2 may be against a DNA fragment located close to the affected gene, it does not include the gene itself. Probe \#3 reveals a DNA fragment that has $100 \%$ correlation with the disease phenotype - all of the affected individuals and none of the unaffected individuals contain this fragment. This probe must be located very close to and may include the affected gene.

transmitting a genetic disease to children, helping people make informed decisions about the risk of having children with genetically transmitted disorders.

\section{PCR and RFLP Analysis}

RFLP analysis generally requires several micrograms of DNA for analysis, an amount easily obtained from a small tissue or blood sample. The technique of polymerase chain reaction (PCR) amplification of DNA is a development that has greatly reduced the amount of DNA necessary to perform genetic screening. Unlike conventional RFLP analysis, PCR analysis can be accomplished with extremely small amounts of DNA. The few cells that remain at the end of a human hair or in a drop of blood, for example, can provide sufficient DNA for the PCR amplification and analysis of specific DNA sequences. The PCR procedure requires more initial information than RFLP analysis, since the nucleotide sequence of the DNA fragment to be amplified must first be determined to allow the design of primers that will flank the region and direct the amplification process. PCR amplification can be combined with Southern blot analysis to allow sensitive examination of specific sequences in extremely small samples of DNA.

\section{DNA Fingerprints}

The principles of RFLP and PCR analysis are frequently applied in a form of DNA characterization called DNA fingerprint analysis. Although the coding regions of most genes show relatively little sequence variability, some regions of the chromosomes have extreme sequence variation. The human genome contains short 
nucleotide sequence elements called satellite DNA that are present in thousands of copies per cell. Many adjacent, repeated copies of a short sequence are present at specific locations in mammalian chromosomes, but the precise number of the repeated copies can be quite variable, causing slight variations in the total size of the region containing the repeated element (Figure 4). The DNA fragments containing this repetitive DNA can be of slightly different sizes in different individuals. Analysis of these repeated elements with either RFLP or PCR methods can lead to a pattern of DNA bands, often called a DNA fingerprint, that can be used to identify the individual from whom the DNA sample was purified.

Matching a DNA fingerprint with a DNA sample is based on the experimental observation that although a region of DNA that contains a repeated element can have variation in the number of copies of the repeat, some copy numbers occur more frequently than other numbers. When DNA samples are isolated from members of the population, a DNA fragment size associated with a particular repeated element might occur with a frequency of 12 times out of 100 individuals $(12 / 100)$ examined. A different fragment size associated with the same repeated sequence might occur much less frequently and be found in only 1/100 individuals examined.

Since people are diploid and have two copies of each chromosome, the DNA fingerprint pattern of an individual will contain the pattern of bands on the chromosome received from the mother plus the pattern of bands on the chromosome received from the father. The overall chances that a DNA sample contains a specific combination of DNA fragments can be expressed by multiplying together the probabilities observed for each of the two chromosomal patterns. The probability that a given individual will have both the band found in $12 / 100$ people and the band found in $1 / 100$ people is $12 / 100 \times 1 / 100=12 / 10,000$ or $0.12 \%$. It would be necessary to examine about 833 different people to find someone who by coincidence alone has the identical pattern of DNA bands. Whether two DNA samples with the same DNA fingerprint are identical can be expressed in terms of the probability of randomly finding two unrelated individuals with the same band patterns.

By using DNA sequence elements that have been demonstrated to have a wide range of variability and by examining the DNA patterns corresponding to several

Figure 4. Short, linearly repeated sequence elements like the sequence CACACGC can be present at different copy numbers in the same region of different chromosomes. Although each member of a pair of chromosomes contains the same genes, one chromosome may contain seven copies of the repeated sequence at a specific location while the other chromosome of the pair has five copies of the repeated sequence. When the two DNA molecules are digested with a restriction enzyme that does not cut within the inserts, like EcoRI, one fragment will be larger than the other. In the example illustrated, one fragment would be two inserts, or 14 bases, larger than the other fragment. Since eukaryotic cells contain pairs of chromosomes, a human cell could be homozygous and have a single DNA band indicating two chromosomes with seven repeat inserts each (7/7), homozygous and have a single DNA band indicating two chromosomes with five repeat inserts each $(5 / 5)$, or heterozygous and have two different bands indicating one chromosome with five repeat inserts and one with seven repeat inserts $(5 / 7)$.

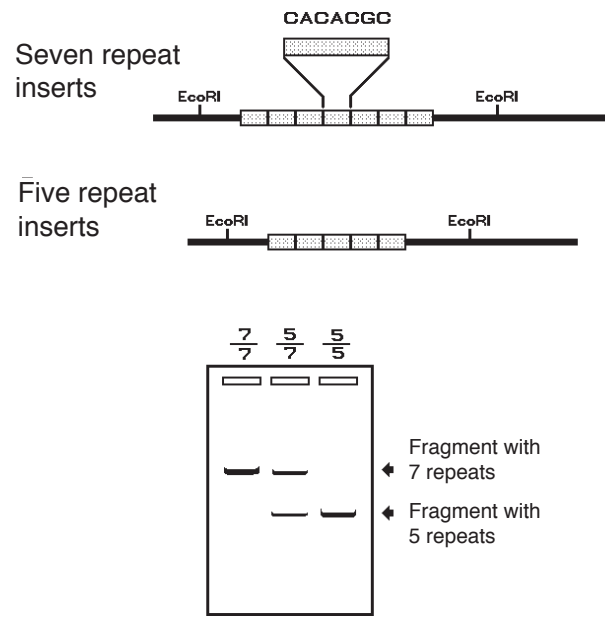


different repeated sequence elements, it is easy to obtain calculated probabilities that are astronomical. If two DNA samples both contain four different bands that occur at a frequency of $1 / 200$ individuals, the total probability of this fragment combination is $1 / 200 \times 1 / 200 \times 1 / 200 \times 1 / 200=1 / 1,600,000,000$. It would, in principle, be necessary to examine $1,600,000,000$ people to find two people that coincidentally have this DNA fingerprint pattern. For sufficiently rare fragment sizes, the calculations can suggest that there are not enough people on the planet to find an identical DNA fingerprint on a purely random basis.

The DNA fingerprint has become a molecular biology tool with increasing legal significance. The DNA fingerprint can be much more conclusive than conventional blood and tissue typing and has been used to decide cases involving alleged paternity of a child. Since a child receives half of its chromosomes from the mother and half from the father, all of the bands in the DNA fingerprint of a baby should match DNA bands present in the DNA fingerprints of either the mother or the father. In principle, bands present in the fingerprint of the baby but absent from the fingerprint of the mother must be present in the fingerprint of the alleged father (Figure 5), or the alleged father cannot be the biological parent of the child.

DNA fingerprinting is a tool with tremendous potential for forensic investigation. A DNA fingerprint can be performed on the DNA extracted from a small amount of tissue left by the perpetrator at the scene of a crime. Some crimes, such as rape, leave tissue samples that allow very reliable DNA fingerprint analysis. PCR technology is so sensitive that a reliable DNA fingerprint can be obtained from the DNA isolated from a drop of blood dried on a victim's clothing, from the skin cells

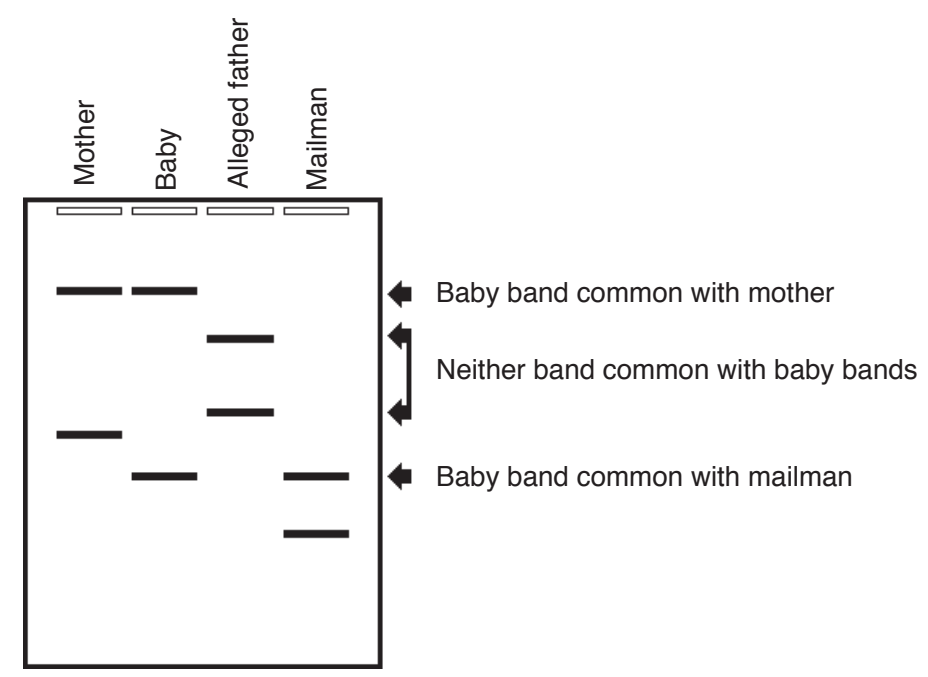

Figure 5. Use of DNA fingerprints to resolve a case of disputed paternity. The mother of a child accuses a man of being the father of her baby and demands child support payments. The alleged father denies the child is his and demands a DNA fingerprint to support his claims. A DNA fingerprint test including DNA isolated from the mother, the baby, the alleged father, and the mailman (included at the recommendation of the alleged father) was prepared. One band observed in the DNA fingerprint of the baby was clearly present in the DNA of the mother, as expected, but the other band present in the baby was not present in the alleged father and neither of the bands observed in the alleged father was present in the baby. Since the bands present in the baby must come from either the mother or the father, these results suggest that the alleged father is not the biological father of the baby. Curiously, the non-maternal band present in the fingerprint of the baby was the same size as one of the bands in the DNA fingerprint of the mailman. This finding does not prove that the mailman is the father of the child (the matching band may be extremely common), but is consistent with this suggestion. 
that lodge under a victim's fingernails when scratching an attacker, or from a hair found at the crime scene. By comparing the DNA fingerprints obtained from these small samples that are often found at the scene of a crime with the DNA fingerprints of principle suspects, it is possible to obtain statistics that either eliminate suspicion of involvement or further implicate a suspect.

\section{The Human Genome Project}

The human genome is believed to contain some 80,000 to 100,000 different genes. The human genome project is an attempt to create a chromosomal genetic map of the locations of all of these genes. This project, which involves the efforts of hundreds of scientists all over the world, involves restriction mapping, genetic analysis, and nucleotide sequence analysis of human chromosomes. To date, the chromosomal locations in excess of 16,000 genes have been identified and the functions of about one quarter of these genes have been determined. It is hoped that completion of this project will facilitate the analysis of many genetic diseases.

\section{Controversy Associated with Application of Genetic Methods}

Relatively little controversy has been associated with the use of molecular biology methods to help couples at risk for genetic disorders decide whether to have children. However, these methods have also significantly increased the ability of physicians to diagnose a variety of fetal genetic disorders following an amniocentesis. Women who are at risk for transmitting a genetic disorder to their children can have the chromosomes of the unborn fetus examined and learn, with a very high degree of probability, whether the child is destined to be a victim of the genetic disorder. A pregancy might then be terminated to avoid giving birth to a genetically doomed child.

Advocates of this genetic technology might argue that the procedures can prevent the unnecessary suffering of both parent and child by allowing selective abortion based on an informed decision about the presence of a genetic disease. Opponents have pointed out that this application represents the first step towards eugenics - the early termination of pregnancy to avoid unwanted characteristics or to select for desired traits in offspring. Where should lines be drawn? If the method is allowed to provide genetic information as justification for abortion, which types of genetic result justify termination of pregnancy? Is the presence of a genetic disease that will result in severe retardation and death by the age of 10 years of the same consequence as the finding that a fetus is male in a family of ten boys and no girls? This is not really a scientific question, but a dilemma that has arisen because of the rapid development and application of scientific methods.

The application of DNA fingerprinting, which is theoretically sound and scientifically reliable, has also been accompanied by controversy. Scientific innovations naturally move from the realm of research facilities to the domain of companies that provide a service or product in exchange for a fee. In the case of DNA fingerprinting for legal identification of individuals, some concern has arisen over both the reliability of the DNA fingerprinting process and the capability of the consumer (the legel system) to evaulate the significance of the results.

In one case where a suspect was convicted of murder, the jury was recorded as stating "you can't argue with science" when confronted with the DNA fingerprint evidence. A significant number of molecular biologists who subsequently examined the same DNA fingerprint data came to a conclusion opposite that presented by the company that performed the tests and convinced the jury! Subsequent testing procedures have revealed levels of error that would be deemed unacceptable for scientific investigations. Although the scientific method might be sound, the quality of the test is limited by the reliability of the individual performing the test and interpreting the data. 
There is also concern that the statistics used to calculate probability of pattern occurrence may not be representative of the occurence of DNA fragment patterns in the general population. A random distribution of genetic markers in the population requires a freely interbreeding and mobile population, which is not a general aspect of the human social condition. A DNA fingerprint pattern that is extremely rare in New York City, for example, can be extremely common in a small isolated town with a high degree of inter-family marriage. The sample populations used to establish the statistics regarding DNA fingerprint pattern frequency may not be large enough to allow application of the statistics outside of the original population. The frequency of occurrence of a DNA fingerprint pattern in New York City, for example, may be quite different from the frequency of occurrence of the same pattern in a small town in New Mexico.

Because the methods are scientifically correct, the concerns regarding quality, reliability, and statistics can all be addressed and corrected. There is, however, a key component of the legal system that is more difficult to alter - the jury. In order to make a reliable decision, it is important that the members of the jury understand the capabilities and limitations of the method in use. For example, while a DNA fingerprint may conclusively prove two DNA samples are different, it cannot prove two samples are identical. It merely provides a statistical argument about probability that two samples are identical. Two DNA samples can have the identical DNA fingerprint, yet have different nucleotide sequences (Figure 6). Resolving the controversy surrounding the application of molecular biology methods to forensic and legal problems will require modifications within the fingerprinting companies and a reasonable general public understanding of molecular biology.

\section{Generation of Vaccines}

The eradication of the variola, the virus that causes smallpox, is without question one of the greatest medical achievements of this century. The elimination of this disease was accomplished by innoculating virtually everyone in the world with

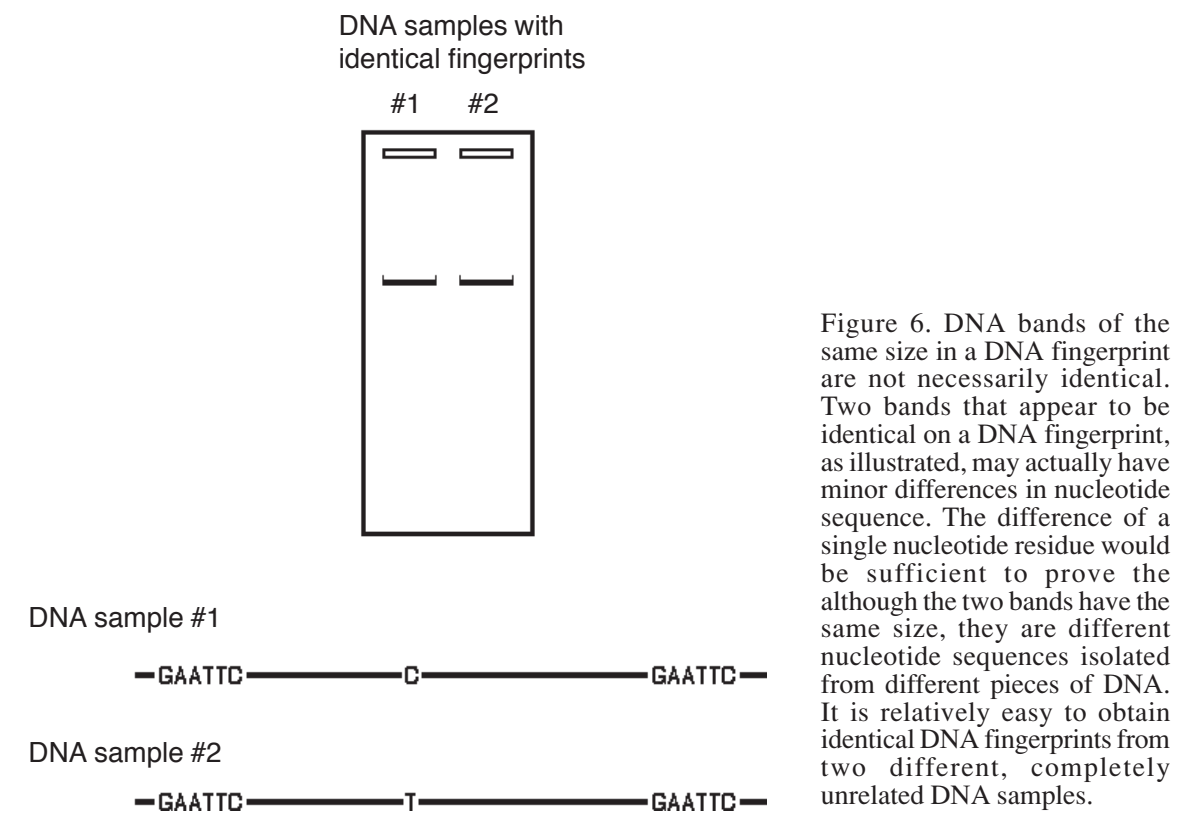


vaccinia, a virus that causes very few symptoms in people but, because of similarity in the surface proteins of vaccinia and variola viruses, raises immunity against the smallpox virus. Since the variola smallpox virus can only propagate in a human host, as increasing numbers of people became immune to variola by vaccination with the related vaccinia virus, the ability of the smallpox virus to spread through the population decreased. Because of the lack of an infectable host, the variola virus eventually disappeared.

The strategy that allowed elimination of smallpox was possible because of a convenient similarity between the surface proteins of the disease-producing variola virus and the relatively harmless vaccinia virus. The similarity between the viruses that allowed the application of this strategy was coincidental and has not generally been found to occur naturally for other combinations of viruses.

Molecular biology has provided the methods that allow this strategy to be applied to generate immunity to other disease-producing viruses (Figure 7). The DNA for a harmless virus like vaccinia can be cleaved with a restriction enzyme and a gene that produces one of the surface proteins of a disease-producing virus inserted into the vaccinia virus. When the vaccinia construct is then used to vaccinate an animal, replication of the recombinant causes the production of not only vaccinia proteins, but also of the extra protein corresponding to the DNA insert. This will cause the formation of antibodies against the viral protein. If the immunized individual is subsequently exposed to the intact infectious virus, the antibodies directed against the coat protein that was carried by the recombinant virus can bind to the protein and inactivate the infectious virus.

The strategy with recombinant vaccines is identical to that used to raise immunity against the smallpox virus - infect the host with a harmless virus that causes the production of antibodies that recognize and inactivate a disease-producing virus. Molecular biology has now circumvented the need to find a naturally existing virus

Figure 7. Viruses that cause only mild symptoms during infection of a host can be used as vectors to carry a gene from a pathogenic virus that normally causes a disease. When the recombinant virus is introduced into the host, replication of the recombinant virus will cause synthesis of viral RNA and proteins. RNA and protein will also be produced from the cloned gene but since the complete pathogenic virus is not present, no disease symptoms will be generated. The immune system can respond to the viral infection by making antibodies against both the normal viral proteins and the cloned viral gene product. The antibody against the pathogenic viral protein can subsequently confer immunity to infection by the intact pathogenic virus.

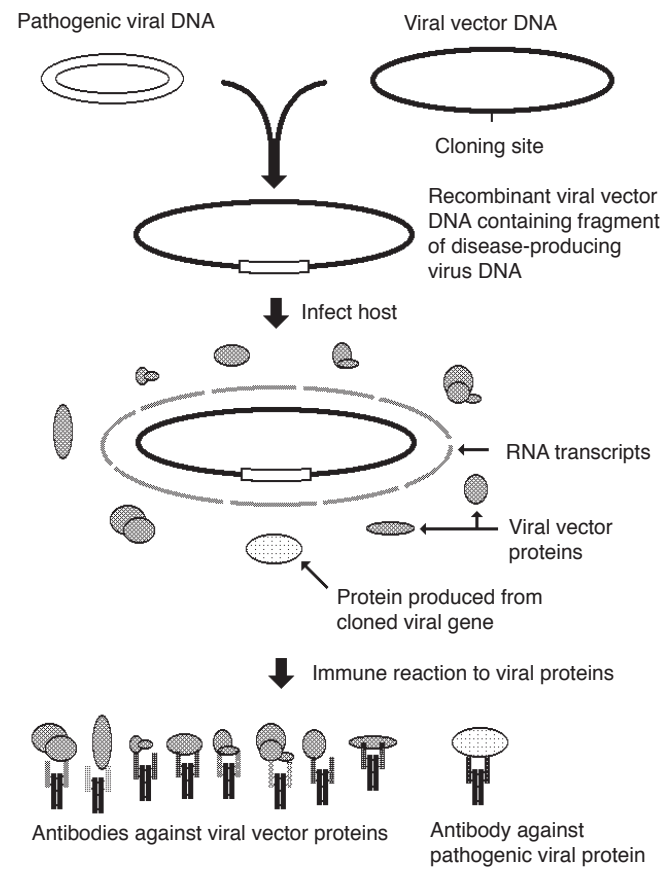


Figure 8. Introduction of a desired trait that is not normally present in an agronomically important species can be accomplished by conventional breeding methods. To introduce insect resistance in a crop plant, a breeder might screen other closely related plants to find an insectresistant plant that is sufficiently related to the crop plant to allow breeding of the two plants. The insect-sensitive crop might be crossed with the insect-resistant relative multiple times in order to acquire and stabilize the desired resistance trait. This breeding program may also introduce undesired characteristics of the insect-resistant relative, so insectresistant progeny of the cross may be bred back to the crop plant parent to recover desired crop characteristics. Obtaining the desired insect-resistant crop plant may require many generations of breeding and may result in loss of some desireable crop plant characteristics.

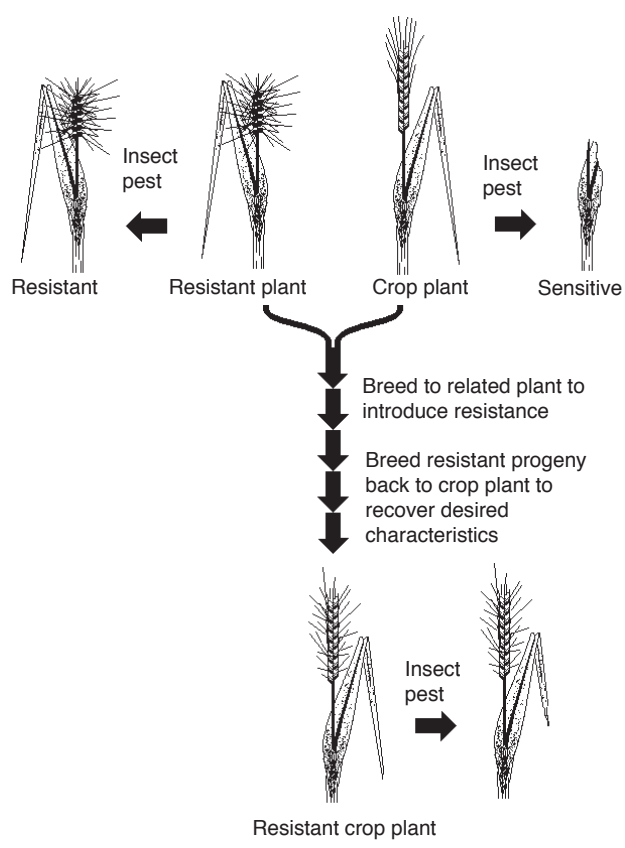

for vaccination. A virus like vaccinia can be used to carry genes isolated from other viruses and raise antibodies that recognize and inactivate the products of the cloned genes. This strategy has been used to generate effective vaccines against a variety of diseases, including rabies and hoof and mouth disease, and is under investigation as a means of generating vaccines against the AIDS family of viruses.

\section{Manipulation of Agronomically Significant Species}

Molecular biology methods have been seen as having tremendous potential for the manipulation of the properties of agronomically significant species. The principal goal of this type of research is to use these methods to isolate genes for desired traits and introduce these genes into plant and animal species that are used for the generation of agricultural products like food, fuels, and textiles. The concept of improving strains is not new. Man has for centuries been using selective breeding and genetic selection to genetically engineer plants and animals. Molecular biology techniques merely facilitate the introduction and establishment of specific desired traits.

A traditional breeding scheme designed to introduce plant resistance to an insect pest might survey all related plants to find a "resistant" plant, a close plant relative that produces a noxious or poisonous compound that repels or kills insect pests. The resistant plant would then be genetically crossed with the crop plant and the progeny crop plants examined for resistance to the insect pest. Since genes that affect the desirable properties of the crop plant (such as yield or flavor) may be introduced during the breeding process, the resistant progeny must be examined relative to unwanted changes in desirable characteristics. Successive rounds of breeding with the crop plant may be necessary to re-establish desired traits in the resistant strain. With successive rounds of breeding and selection, the desired insect resistance trait might be bred into the plant to generate an improved crop plant (Figure 8). While this strategy has been successful for hundreds of genetic modifications of plants and animals, the process can be tedious, slow, and limited by sexual and species transmission barriers (genes from a sunflower plant, for example, cannot be sexually transferred to a potato plant). 


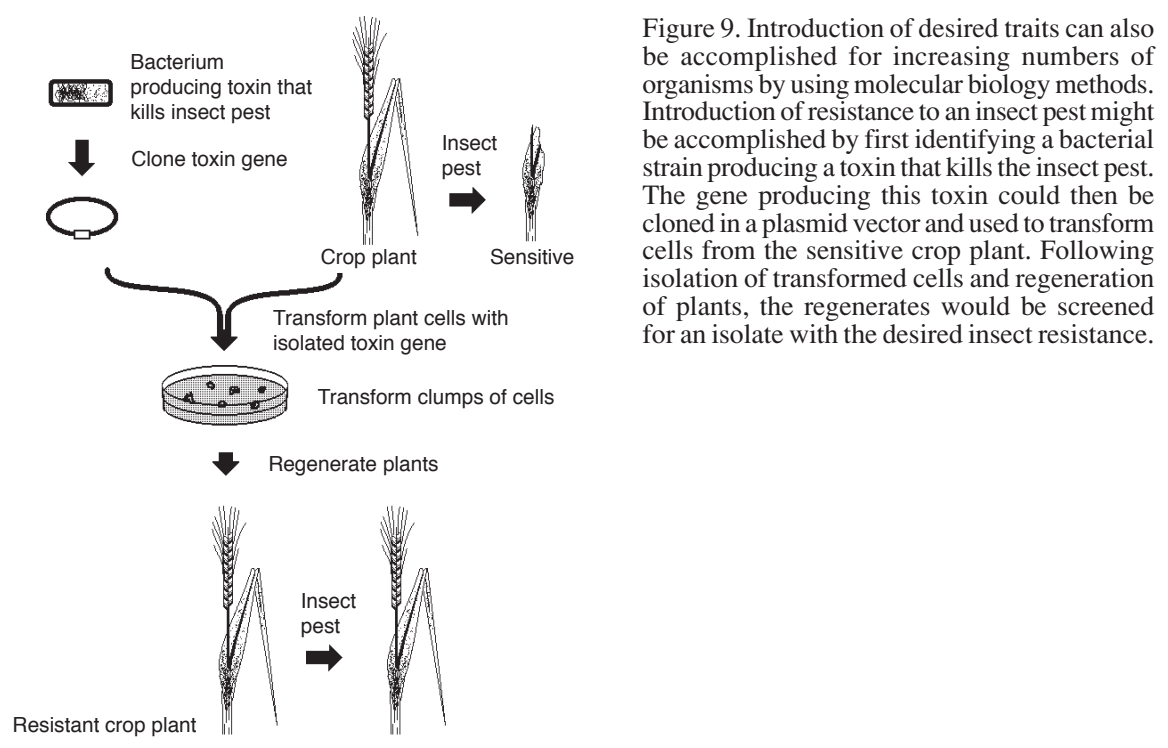

A strategy that involves molecular biology methods (Figure 9) would also first identify a gene product that will provide the desired insect resistance, but the species containing the desired gene need not be present in a plant related to the crop of interest. The gene may be identified in a completely unrelated plant species, an animal, or a strain of bacteria. The desired gene would then be isolated, characterized, and fused to a transcription regulation region that will function in the crop plant. The engineered resistance gene can then be introduced by transformation into the desired plant host and progeny that express the desired trait selected. Unlike the convential genetic approach, the desired trait is the only gene introduced during the procedure and repeated rounds of breeding are not necessary to remove undesired traits frequently acquired during conventional genetic schemes.

Molecular biology methods are currently being applied to a variety of agronomic problems to transfer genes across genetic species barriers and create plants and animals that express novel gene products. This application of these methods has led to public concern regarding a variety of issues. It has been suggested that genes introduced into a crop plant may subsequently be inadvertently sexually transferred to closely related weed species, that manipulation of the genome may lead to a decrease in genetic purity of a species, and release of the engineered strains into the environment may adversely affect native species. In a widely publicized controversy regarding the use of a strain of bacterium designed to outcompete resident bacteria involved in ice crystal nucleation and frost damage of strawberry plants, allegations were made that release of the genetically engineered bacteria might result in alteration of atmospheric weather patterns.

A wide variety of concerns have been raised regarding the use of genetically engineered organisms. These issues range from scientific concerns regarding the release of engineered organisms into an increasingly stressed biosphere to allegations regarding the morality of manipulating the genes of organisms. Perhaps because of the power of molecular biology to manipulate and modify the genomes of organisms, there has been significant emphasis on the potential contribution of this technology to agricultural production. As is often the case, the development and application of this powerful new technology has been accompanied by increasing amounts of public concern and controversy.

Further reading: An Introduction to Molecular Biology. Robert C. Tait. Horizon Scientific Press, Wymondham, UK. (ISBN: 1-898486-08-5) 


\section{Further Reading}

Caister Academic Press is a leading academic publisher of advanced texts in microbiology, molecular biology and medical research. Full details of all our publications at caister.com

- MALDI-TOF Mass Spectrometry in Microbiology Edited by: M Kostrzewa, S Schubert (2016) www.caister.com/malditof

- Aspergillus and Penicillium in the Post-genomic Era Edited by: RP Vries, IB Gelber, MR Andersen (2016) www.caister.com/aspergillus2

- The Bacteriocins: Current Knowledge and Future Prospects Edited by: RL Dorit, SM Roy, MA Riley (2016)

www.caister.com/bacteriocins

- Omics in Plant Disease Resistance Edited by: V Bhadauria (2016) www.caister.com/opd

- Acidophiles: Life in Extremely Acidic Environments Edited by: R Quatrini, DB Johnson (2016) www.caister.com/acidophiles

- Climate Change and Microbial Ecology: Current Research and Future Trend

Edited by: J Marxsen (2016)

www.caister.com/climate

- Biofilms in Bioremediation: Current Research and Emerging Technologies

Edited by: G Lear (2016)

www.caister.com/biorem

- Microalgae: Current Research and Applications Edited by: MN Tsaloglou (2016) www.caister.com/microalgae

- Gas Plasma Sterilization in Microbiology: Theory, Applications, Pitfalls and New Perspectives Edited by: H Shintani, A Sakudo (2016) www.caister.com/gasplasma

- Virus Evolution: Current Research and Future Directions Edited by: SC Weaver, M Denison, M Roossinck, et al. (2016) www.caister.com/virusevol

- Arboviruses: Molecular Biology, Evolution and Control Edited by: N Vasilakis, DJ Gubler (2016) www.caister.com/arbo

- Shigella: Molecular and Cellular Biology Edited by: WD Picking, WL Picking (2016) www.caister.com/shigella

-Aquatic Biofilms: Ecology, Water Quality and Wastewater Treatment

Edited by: AM Romaní, H Guasch, MD Balaguer (2016)

www.caister.com/aquaticbiofilms

- Alphaviruses: Current Biology

Edited by: S Mahalingam, L Herrero, B Herring (2016)

www.caister.com/alpha

- Thermophilic Microorganisms

Edited by: F Li (2015)

www.caister.com/thermophile
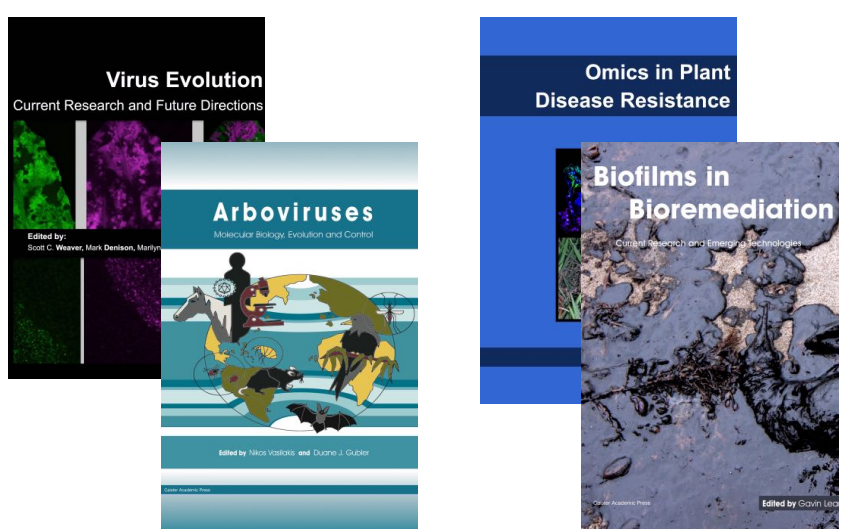
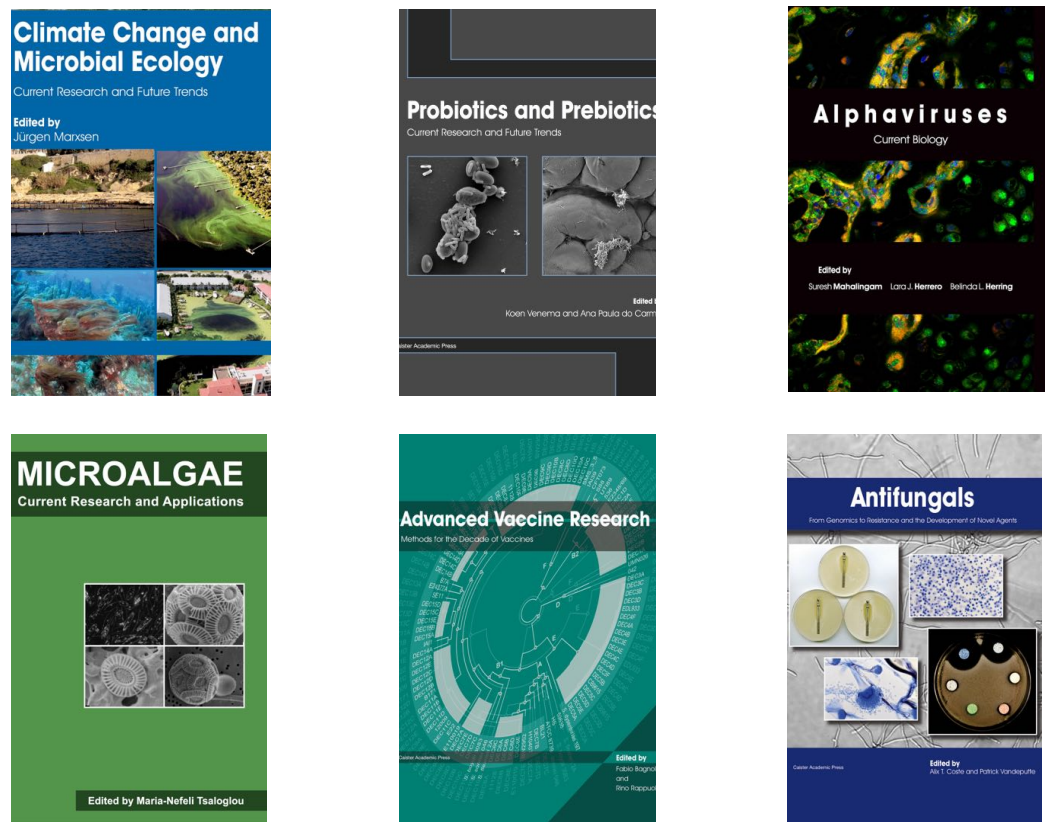

- Flow Cytometry in Microbiology: Technology and Applications Edited by: MG Wilkinson (2015) www.caister.com/flow

- Probiotics and Prebiotics: Current Research and Future Trends Edited by: K Venema, AP Carmo (2015) www.caister.com/probiotics

- Epigenetics: Current Research and Emerging Trends Edited by: BP Chadwick (2015) www.caister.com/epigenetics2015

- Corynebacterium glutamicum: From Systems Biology to Biotechnological Applications

Edited by: A Burkovski (2015)

www.caister.com/cory2

- Advanced Vaccine Research Methods for the Decade of Vaccines

Edited by: F Bagnoli, R Rappuoli (2015)

www.caister.com/vaccines

- Antifungals: From Genomics to Resistance and the Development of Novel Agents

Edited by: AT Coste, P Vandeputte (2015)

www.caister.com/antifungals

- Bacteria-Plant Interactions: Advanced Research and Future Trends Edited by: J Murillo, BA Vinatzer, RW Jackson, et al. (2015) www.caister.com/bacteria-plant

\section{- Aeromonas}

Edited by: J Graf (2015)

www.caister.com/aeromonas

- Antibiotics: Current Innovations and Future Trends

Edited by: S Sánchez, AL Demain (2015)

www.caister.com/antibiotics

- Leishmania: Current Biology and Contro Edited by: S Adak, R Datta (2015) www.caister.com/leish2

- Acanthamoeba: Biology and Pathogenesis (2nd edition) Author: NA Khan (2015)

www.caister.com/acanthamoeba2

- Microarrays: Current Technology, Innovations and Applications Edited by: Z He (2014)

www.caister.com/microarrays2

- Metagenomics of the Microbial Nitrogen Cycle: Theory, Methods and Applications

Edited by: D Marco (2014)

www.caister.com/n2 